\title{
Irradiance availability and growth of leguminous trees of cerrado
}

\section{Disponibilidade de irradiância e crescimento de leguminosas arbóreas do cerrado}

\author{
Carlos César Ronquim¹, Carlos Henrique Britto de Assis Prado ${ }^{2}$ e João Paulo Souza ${ }^{3}$
}

\begin{abstract}
Resumo
Avaliamos o desempenho fotossintético, o crescimento e a partição da biomassa nas espécies arbóreas Anadenanthera falcata e Stryphnodendron adstringens crescendo em regimes de irradiância solar plena e sob o dossel equivalente à fisionomia de um Cerradão. O estudo foi conduzido livre de estresse hídrico por meio de rega na cidade de São Carlos, estado de São Paulo, Brasil, até 1140 dias após a semeadura (DAS). As medidas de irradiância e de trocas gasosas foliares foram realizadas por meio de um analisador de gases por infravermelho. Em sol pleno as espécies apresentaram valores maiores de capacidade fotossintética regular e potencial, respiração no escuro, ponto de saturação à luz e de eficiência de carboxilação aparente. Nessa área ensolarada a altura, o diâmetro do caule, a área foliar e o número total de folíolos foram significativamente maiores $(p<0,05)$ em ambas as espécies aos 240,360 e aos 570 DAS. Após 1140 DAS sob o sombreamento nenhum indivíduo de $S$. adstringens sobreviveu, mas todos os indivíduos de $A$. falcata resistiram. Nossos resultados demonstraram como a disponibilidade natural da irradiância determinou, per se, o balanço de carbono, o desenvolvimento e a sobrevivência das espécies arbóreas na vegetação do Cerrado.
\end{abstract}

Palavras-chave: área foliar, balanço de carbono, fotossíntese líquida, partição de biomassa, sobrevivência

\begin{abstract}
We evaluated photosynthetic performance, growth, and biomass partitioning in tree species Anadenanthera falcata and Stryphnodendron adstringens growing under full solar irradiance and in the shade equivalent to that found in understory of the Cerradão physiognomy. The study was conducted free of water stress by watering, in São Carlos, state of São Paulo, Brazil, until 1140 days after sowing (DAS). We obtained irradiance and leaf gas exchange data with a portable infrared gas analyzer. In the sunny area, both species presented higher respiration in the dark, light saturation point, regular and potential photosynthetic capacity and higher apparent carboxylation efficiency. Besides, under full solar irradiance, the total biomass, leaf area, height, stem diameter, and the total number of leaflets were significantly $(p<0.05)$ higher at 240 , 360 , and 570 DAS. S. adstringens did not survive in the shade after 1140 DAS, while $A$. falcata showed a survival of $100 \%$ under both irradiance regimes. The irradiance attenuation in dense physiognomies of cerrado vegetation, as that found in Cerradão, affected several levels of plant organization since early growth. Our results highlighted how natural irradiance availability in Cerrado vegetation determined per se the carbon balance, the development and the survival of tree species.
\end{abstract}

Keywords: biomass partitioning, carbon balance, leaf area, net photosynthesis, survival.

\section{INTRODUCTION}

The Cerrado is the largest neo-tropical savanna, the second most extensive vegetation domain in South America. The main factors influencing Cerrado structure are fire, low soil fertility, high evaporative demand and the seasonality of rainfall (HARIDASAN, 2008; OLIVEIRA-FILHO; RATTER, 2002; OLIVEIRA-FILHO et al., 1989). The high spatial variation in the density of woody plants across Cerrado physiognomies results in different patterns of irradiance availability under canopy. The limited irradiance in Cerrado physiognomies is a constraint to carbon balance. It happens in the understory of the Cerradão or under the grass layer in campo sujo (KANEGAE et al., 2000; RONQUIM et al., 2003; FRANCO, 2005; PRADO et al., 2005; RONQUIM et al., 2009; RONQUIM et al. 2013).

${ }^{1}$ Pesquisador Doutor. EMBRAPA - Empresa Brasileira de Pesquisa Agropecuária. Centro Nacional de Monitoramento por Satélite. Av. Soldado Passarinho, 303 - Fazenda Chapadão - 13070-115 - Campinas, SP, Brasil. E-mail: carlos.ronquim@ embrapa.br.

2Professor Titular do Departamento de Botânica. UFSCar - Universidade Federal de São Carlos. Rodovia Washington Luís SP 310, Km 235 - 13.565-905 - São Carlos, SP, Brasil. E-mail: kiq.prado@gmail.com.

3Professor Adjunto no Instituto de Ciências Biológicas e da Saúde. UFV - Universidade Federal de Viçosa. Campus Florestal - Rodovia MG 818 KM 6 - 35690-000 - Viçosa, MG, Brasil. E-mail: joaopaulobio@hotmail.com.

Sci. For., Piracicaba, v. 46, n. 117, p. 115-126, mar. 2018 DOI: dx.doi.org/10.18671/scifor.v46n117.11 
The leaves of Cerrado woody species typically reach $90 \%$ of their maximum photosynthetic values (Amax) at a photosynthetic photon flux density (PPFD) between $600-1200 \mu \mathrm{mol} \mathrm{m}^{-2} \mathrm{~s}^{-1}$ (PRADO; MORAES 1997). Indeed, the differences in tree distribution across Cerrado physiognomies may reflect the shade tolerance during the lifecycle of a woody species (FRANCO, 2002; PRADO et al., 2005; RONQUIM et al., 2009). Young plants of woody species of Cerrado vegetation growing in the shade show morphological adjustments to offset the low irradiance effects (HOFFMANN; FRANCO, 2003; RONQUIM et al., 2009; RONQUIM et al., 2013).

In a previous study on Copaifera langsdorffii Desf. (RONQUIM et al., 2009), a species with a wide distribution in Cerrado vegetation, the performance of growth and net photosynthesis was better in sunny versus shaded areas. Copaifera langsdorffi growing in sunny areas showed high values of photosynthetic capacity, biomass accumulation, respiration in the dark and a high light compensation point. On the other hand, individuals in shaded areas showed large leaf area ratio and high chlorophyll content. These morphological and physiological adjustments allow species such as $C$. langsdorffii to persist in contrasting light environments and may explain the widespread occurrence of this tree species in the Cerrado and forests in Brazil.

Both species studied are found virtually in all woody physiognomies of Cerrado, but they differ in the preferential niche. Anadenanthera falcata (Benth.) Speg. is one of the most widespread tree species, and Stryphnodendron adstringens (Mart.) Coville is a common tree only in open areas of the Cerrado (DURIGAN et al., 2003). Due to the differences in a preferential niche, we assumed that $A$. falcata would have a better carbon balance in the shade than $S$. adstringens. To test this expectation, we determined the photosynthetic responses and followed the growth in both species in the understory (shaded) and in open (sunny) areas up to 570 days after sowing (DAS). The positive (net photosynthesis) and negative (respiration in the dark) components of transitory carbon balance were evaluated using leaf gas exchange with total biomass and its partitioning in the plant compartments. We studied the effects of natural irradiance availability on individuals free of water stress up to 570 DAS since the rainfall distribution along the year strongly influences carbon assimilation in woody species of Cerrado (PRADO et al., 2004). Therefore, we could evaluate the effects in isolation of natural irradiance availability on carbon balance, growth, development and persistence in field.

By growing in the field two common leguminous trees free of water stress under contrasting natural irradiance we specifically addressed two questions: 1) Does natural shade unaccompanied by water shortage influence significantly the carbon balance as of the early growth? 2) Are there significant morphological and physiological adjustments in various levels of plant organization that provide competences for the successful establishment? Therefore, the objective of this work was to determine, studying leaf gas exchange and biomass partitioning, how and how much growth and carbon balance are modified in trees free of water shortage in Cerrado vegetation, facing contrasting natural irradiance availability in field.

We hypothesized that the natural availability of irradiance in the Cerrado per se is a crucial ambient factor for changing tree features from the molecular to the whole plant level starting from the first months of life. These changes will define patterns of growth, development and the establishment of trees conditioning reciprocally the availability of irradiance and the shape of cerrado physiognomies. The knowledge of these dynamics across several levels of plant organization and the responses of each species are fundamental for the management and conservation of Cerrado vegetation areas.

\section{MATERIAL AND METHODS}

\section{Sowing, watering regime, soil, and climate}

We collected seeds from adult plants grown in a Cerrado reservoir comprising 86 ha at $850 \mathrm{~m}$ above sea level at the Federal University of São Carlos, São Carlos, Brazil (21 $58^{\prime}$ and $22^{\circ} 00^{\prime} S$ $47^{\circ} 51^{\prime}$ and $\left.47^{\circ} 52^{\prime} \mathrm{W}\right)$. Seeds were sown in plastic recipients with $10 \mathrm{~L}$ capacity with only one plant per recipient. During the whole experiment, the soil was irrigated to field capacity just after superficial dehydration. Therefore, every plant grew free of water stress up to 570 days after sowing (DAS). The soil utilized was an Oxisol collected from the superficial layer $(0-20 \mathrm{~cm})$ in previously described Cerrado reservoir. The following soil chemical characteristics were determined by "Plant and soil 
analysis laboratory" at São Paulo State University (UNESP): $26 \mathrm{~g} \mathrm{dm}^{-3}$ of total organic matter, pH of 3.9 under $\mathrm{CaCl}_{2}$ centimolar solution, cation exchange capacity of $63.3 \mathrm{mmol}_{\mathrm{c}} \mathrm{dm}^{-3}$, and saturation base (V\%) equal to 8.0. The other chemical soil traits were $4 \mathrm{mg} \mathrm{dm}^{-3}$ of phosphorus and 1.3, 3.0, and $1.0 \mathrm{mmol}_{c} \mathrm{dm}^{-3}$ of potassium, calcium, and magnesium, respectively. The regional climate is seasonal with a dry winter followed by a wet summer fitting in Cwa category in the Köppen climatic classification. The historical (1939-2007) average values \pm SD of the annual precipitation and the air temperature were $1,420 \pm 168 \mathrm{~mm}$ and $22 \pm 0.4{ }^{\circ} \mathrm{C}$, respectively (SOUZA et al., 2011).

\section{Irradiance regimes, number of plants, biomass and biometric measurements at 240, 360 and 570 days after sowing (DAS)}

Seedlings grew under full solar irradiance (sunny area) on $50 \mathrm{~m}^{2}$ in the experimental garden of Department of Botany in São Carlos Federal University or on $50 \mathrm{~m}^{2}$ in the understory (shaded area) of a forest fragment next to the sunny area. We determined the daily irradiance in the sunny area or in understory using a Parkinson Leaf Chamber (model PCL-N, ADC, Hoddesdon, UK) connected to a console of a portable infrared gas analyzer (model LCA-4, ADC, Hoddesdon, UK). We obtained the photosynthetic photon flux density (PPFD, Figure 1) in both irradiance regimes during clear days at the partial canopy leaf fall (July, dry period) and at full canopy leaf area (November, wet period). The irradiance conditions in the understory of a forest fragment along the year were comparable to those obtained by Kanegae et al. (2000) and Prado et al. (2005) in the understory of the Cerradão, the densest physiognomy of Cerrado vegetation (EITEN, 1972).

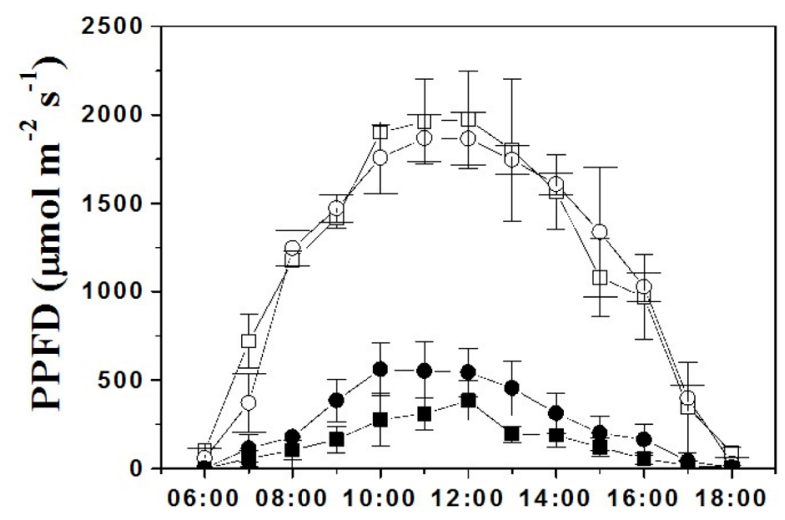

\section{Time of day}

Figura 1. Diurnal course of Photosynthetic Photon Flux Density (PPFD, $\mu \mathrm{mol} \mathrm{m}^{-2} \mathrm{~s}^{-1}$ ) where individuals of $A$. falcata and S. adstringens were cultivated up to 1140 days after sowing. Mean values (symbols) and standard deviation (vertical lines). The results in dry season represented by circles and in wet season by squares. Full solar irradiance on sunny area: $\bigcirc$ and $\square$. Irradiance in shade in understory: $\bullet$ and $\mathbf{m}$.

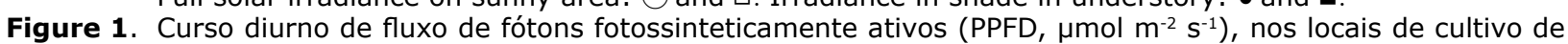
indivíduos de $A$. falcata e de $S$. adstringens até 1140 dias após a semeadura. Estação seca representada por círculos e estação chuvosa por quadrados. Irradiância solar plena em área aberta: $\bigcirc$ e $\square$. Irradiância no sub-bosque sombreado: • e $\mathbf{E}$

We maintained fifty plants per species at each irradiance regime. Three measurements, each one at 240, 360 and 570 days after sowing (DAS), were carried out for biomass and biometric determinations between March-January. Ten individuals per treatment at every irradiance regime were used at each destructive harvest per time of measurement (240, 360 and 570 DAS). Therefore, at each harvest, 10 individuals were indiscriminately chosen, separated into roots, shoots, and leaves and dried at $70^{\circ} \mathrm{C}$ to constant mass (CORNELISSEN et al., 2003). The plant mortality was monitored and the number of dead individuals did not affect the number of plants used for the biomass and biometric determinations in each period of harvest up to 570 DAS (240, 360, and 570 DAS).

\section{Measurements on leaflets, stem, roots and the survivorship up to 1140 days after sowing (DAS)}

The leaf/area ratio (LAR, $\mathrm{cm}^{2} \mathrm{~g}^{-1}$ ) was calculated by dividing the total leaf area by the plant dry mass. Leaflets were collected to determine the leaf mass per area (LMA, $\mathrm{g} \mathrm{m}^{-2}$ ). The average values of LMA were obtained from ten different individuals in each irradiance treatment each time of biomass 
and biometric measurement (240, 360 and 570 DAS). The leaf discs comprised 15 discs per plant, each disc from a different expanded leaf. Leaf discs were oven-dried at $70^{\circ} \mathrm{C}$ to constant mass and weighed separately. Considering the impracticability of removing leaf discs due to the small size of the leaflets in A. falcata, smaller than $5 \mathrm{~mm}$, the rectangular expanded leaflet itself was used to determine the LMA using 15 leaflets per plant. We calculated LMA by dividing the mass of each disc in $S$. adstringens or a set of leaflets in A. falcata per their corresponding leaf area (PRADO; MORAES, 1997).

The height of the plants $(\mathrm{cm})$ was determined using a millimeter ruler from the root collar to the insertion of the last leaf. We determined the stem diameter $(\mathrm{mm}$ ) with a digital caliper (Mitutyo Inc., Japan) $20 \mathrm{~mm}$ from the soil surface. Leaflets were separately collected from each plant, counted and scanned, and the area $\left(\mathrm{mm}^{2}\right)$ was determined using Pro-Image 4.0 for Windows, American Media Cybernetics, Silverspring, Maryland, USA. After the last harvest at 570 DAS, we transplanted eight individuals of each species directly into Cerrado soil under the same irradiance conditions where they were sowed. These eight individuals of every species were maintained under natural conditions for determination the survival, height, and stem diameter up to 1140 DAS.

\section{Leaf gas exchange}

The net photosynthesis $\left(\mathrm{A}, \mu \mathrm{mol} \mathrm{m} \mathrm{m}^{-2} \mathrm{~s}^{-1}\right)$ derived from the photosynthetic photon flux density

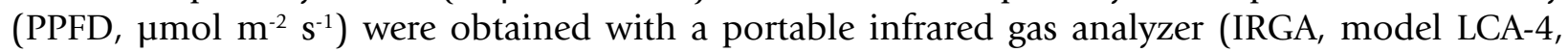
ADC, Hoddesdon, UK) connected to a Parkinson Leaf Chamber (model PLCN-4, ADC) and to a dichroic light cannon (model PLU-002, ADC). During the photosynthesis measurements, the leaflet temperature was maintained between 25 and $27^{\circ} \mathrm{C}$ by a Peltier system connected to PLCN-4. The PPFD values between $800-2000 \mu \mathrm{mol} \mathrm{m}^{-2} \mathrm{~s}^{-1}$ were controlled by the voltage applied up to 12 $\mathrm{V}$ in the light cannon. We attenuated the photon density under $800 \mu \mathrm{mol} \mathrm{m} \mathrm{m}^{-2} \mathrm{~s}^{-1}$ by decreasing the voltage applied and fitting neutral glass filters (Comar Instruments, Cambridge, UK).

Three individuals of both species were utilized to determine net photosynthesis through PPFD, atmospheric $\mathrm{CO}_{2}$, or sub-stomata $\mathrm{CO}_{2}$ concentrations in each irradiance regime at 240, 360 and 570 DAS. Five completely expanded leaflets without signs of injury or senescence were first measured from those same three individuals of each species to determine the highest value of net photosynthesis (A). These leaflets were located on the branches totally exposed to the full available solar irradiance in each treatment.

The leaflet that showed the highest A value under PPFD at $1000 \mu \mathrm{mol} \mathrm{m}{ }^{-2} \mathrm{~s}^{-1}$ was chosen to perform the A-PPFD or the A-CO $\mathrm{CO}_{2}$ curves at 240, 360 and 570 DAS. The leaflet was drawn and scanned for determining the area $\left(\mathrm{mm}^{2}\right)$ using the software Pro-Image 4.0 for Windows, American Media Cybernetics, Silverspring, Maryland, USA.

We obtained A-PPFD before the A-CO ${ }_{2}$ curves in order to calculate the light saturation point (LSP) in each irradiance regime using the following equation (PRADO; MORAES, 1997):

$$
\left.A=A_{\text {max. }}\left(1-e^{-k .(P P F D}-\mathrm{Lc}\right)\right)
$$

Where: $\mathrm{A}_{\max }=$ Maximum net photosynthesis $\left(\mu \mathrm{mol} \mathrm{m} \mathrm{m}^{-2} \mathrm{~s}^{-1}\right) ; \mathrm{e}=$ Euler constant; $\mathrm{k}=$ Constant of proportionality; PPFD = Photosynthetic photon flux density $\left(\mu \mathrm{mol} \mathrm{m}^{-2} \mathrm{~s}^{-1}\right)$; Lc = Light compensation point $\left(\mu \mathrm{mol} \mathrm{m} \mathrm{m}^{-2} \mathrm{~s}^{-1}\right)$.

From the A-CO ${ }_{2}$ curves, the IRGA LCA- 4 could determine the values of sub-stomata $\mathrm{CO}_{2}$ concentration $\left(\mathrm{C}_{\mathrm{i}}\right)$. The $\mathrm{C}_{\mathrm{i}}$ values were used to build up A-C $\mathrm{C}_{\mathrm{i}}$ curves and to obtain the apparent carboxylation efficiency ( $\mathcal{E}$, CAEMMERER, 2000; PRADO et al. 2005; MONTEIRO; PRADO, 2006). The A-PPFD and $\mathrm{A}_{-} \mathrm{CO}_{2}$ curves were done out in the morning, 07:00-09:00 hs. The LSP ( $\mu$ mol photon $\left.\mathrm{m}^{-2} \mathrm{~s}^{-1}\right)$ was calculated at $90 \%$ of $A_{\text {max }}$ and the leaf respiration in the dark $\left(\mathrm{R}_{\mathrm{d}^{\prime}} \mu \mathrm{mol} \mathrm{CO} \mathrm{C}^{-2} \mathrm{~s}^{-1}\right)$ was obtained at zero PPFD (Equation I). The estimation of the apparent quantum yield of $\mathrm{CO}_{2}$ assimilation $\left(\alpha, \mu \mathrm{mol} \mathrm{CO}\right.$ per incident photosynthetic active photon $\left.\mathrm{m}^{-2} \mathrm{~s}^{-1}\right)$ was obtained from the first derivation of equation I (MONTEIRO; PRADO, 2006):

$$
\alpha=\mathrm{k} \cdot \mathrm{A}_{\max } \cdot\left(\mathrm{e}^{\mathrm{k} . \mathrm{Lc}}\right)
$$

The photosynthetic capacity values on a mass basis $\left(\mathrm{A}_{\operatorname{maxm}^{\prime}} \mu \mathrm{mol} \mathrm{CO} \mathrm{Cg}^{-1} \mathrm{~s}^{-1}\right)$ were determined by dividing the photosynthetic capacity on area basis per mean value of LMA (PRADO; MORAES, 1997).

We obtained the $\mathrm{A}_{-} \mathrm{C}_{\mathrm{i}}$ curves using a gas dilutor (model GD-602, ADC, Hoddesdon, UK) connected to a cylinder containing $1800 \mathrm{vpm}$ of $\mathrm{CO}_{2}$ (White Martins, Sertãozinho, SP, Brazil). The cylinder was connected to the gas dilutor GD-602 and linked to the LCA-4 as a half-open system. The air 
taken from the dilutor was first analyzed in LCA-4. This air volume reached the PLCN-4 chamber with the leaf and returned to the LCA- 4 where it was analyzed again and discharged. We carried out each A- $\mathrm{C}_{\mathrm{i}}$ curve recording 4-7 values of $\mathrm{A}$ at each $\mathrm{CO}_{2}$ concentration from 1600 to $20 \mathrm{ppm}$. Starting from $1600 \mathrm{ppm}$, each dilution resulted in $90 \%$ of the previous $\mathrm{CO}_{2}$ concentration (MONTEIRO; PRADO, 2006). The values of PPFD for saturating net photosynthesis in full solar irradiance (1800 $\left.\mu \mathrm{mol} \mathrm{m}{ }^{-2}\right)$ and in shade $\left(900 \mu \mathrm{mol} \mathrm{m}^{-2} \mathrm{~s}^{-1}\right)$ were used in A-CO ${ }_{2}$ curves on leaflets grown in open and in shaded areas, respectively. All three $\mathrm{A}-\mathrm{CO}_{2}$ curves obtained in each irradiance regime were adjusted using the equation (I), replacing the components of light by $\mathrm{CO}_{2}$ components (MONTEIRO; PRADO, 2006):

$$
A=A_{\text {pot. }}\left(1-e^{-k .(C C-\Gamma)}\right)
$$

Where: $\mathrm{A}_{\mathrm{pot}}=$ Potential photosynthetic capacity $\left(\mu \mathrm{mol} \mathrm{m} \mathrm{m}^{-2} \mathrm{~s}^{-1}\right) ; \mathrm{CC}=\mathrm{CO}_{2}$ concentration (ppm); $\Gamma=\mathrm{CO}_{2}$ compensation point $(\mathrm{ppm})$

The A- $\mathrm{C}_{\mathrm{i}}$ curves were obtained from the data acquired in the $\mathrm{A}-\mathrm{CO}_{2}$ curves, changing the $\mathrm{CO}_{2}$ atmospheric by the corresponding sub-stomata $\mathrm{CO}_{2}$ concentration $\left(\mathrm{C}_{\mathrm{i}}\right)$ calculated by LCA-4. We estimated the apparent carboxylation efficiency $\left(e, \mathrm{~mol} \mathrm{~m}^{-2} \mathrm{~s}^{-1}\right)$ in A-C $\mathrm{C}_{\mathrm{i}}$ curves by calculating the first derivate of equation (III) as indicated by Prado et al. (2005) and Monteiro and Prado (2006):

$$
\varepsilon=\mathrm{kA}_{\max } \mathrm{e}^{\mathrm{k} \Gamma}
$$

Therefore, from A-PPFD or A-CO $\mathrm{CO}_{2}$ curves, it was possible to obtain three values of $\mathrm{A}_{\text {maxa }} \mathrm{A}_{\text {maxm }}$, Lc, LSP, a, $R_{d^{\prime}} A_{\text {pot }^{\prime}}$ and e, each one at 240, 360 and 570 DAS. From these three values for every variable we obtained the corresponding averages \pm standard deviation in both irradiance regimes.

\section{Statistical Analyses}

We applied the Lilliefors test to check for normality of morphological, biometrical and irradiance datasets. The Student t test at $\mathrm{p}<0.05$ was applied a posteriori to verify significant differences in average values in each plant biomass and biometric variables and about irradiance mean values between sunny and shaded environments as well as in same light regime between seasons.

\section{RESULTS}

There was no significant difference in mean values of daily irradiance between seasons in same area, Figure 1 . However, there was a significant difference $(\mathrm{p}<0.05)$ in mean values of daily irradiance comparing open and understory areas in the same season. In effect, the average values of PPFD did not achieve $600 \mu \mathrm{mol} \mathrm{m}^{-2} \mathrm{~s}^{-1}$ during daily courses in the understory, which is significantly restrictive to reach maximum net photosynthesis at a regular atmospheric $\mathrm{CO}_{2}$ concentration in Cerrado woody species (PRADO; MORAES, 1997).

The contrasting irradiances did not influence the survival of A. falcata, which had a $100 \%$ survivorship up to 570 DAS. On the other hand, S. adstringens exhibited $100 \%$ of survival only in the open area. In the understory, $24 \%$ of saplings of S. adstringens died at 570 DAS. Indeed, no saplings of $S$. adstringens survived in the understory at 1140 DAS. In contrast, all saplings of A. falcata survived in the understory up to 1140 DAS. At this time A. falcata $(n=8)$ presented in shade $0.40 \pm 0.1$ and $42.5 \pm 12.1 \mathrm{~cm}$ of stem diameter and height, respectively, and in open area $0.80 \pm 0.2$ and $77.6 \pm 9.0$ $\mathrm{cm}$ in that order. For $S$. adstringens under full solar irradiance at 1140 DAS, the values of stem diameter and height were $0.79 \pm 0.2$ and $46.0 \pm 7.4 \mathrm{~cm}$, correspondingly $(\mathrm{n}=8)$.

Significant $(\mathrm{p}<0.05)$ and negative effects on total biomass, stem diameter, total leaf area, LMA and on the number of leaflets were observed in shaded individuals for all periods of measurements in both species up to 570 DAS (Figure 2). In sunny areas, A. falcata presented a higher biomass gain than $S$. adstringens in all three measurements resulting in a total biomass two times higher at 570 DAS. The higher capacity to allocate biomass into the stem and foliage resulted in low values of root/shoot ratio, advanced areal space acquisition via greater height and larger stem diameter in $A$. falcata versus $S$. adstringens, especially at 570 DAS, Figure 2. On the other hand, the leaf area per unit plant mass (leaf area ratio, LAR) was significantly higher in shaded versus sunny area in both species across all measurements, 240, 360 and at 570 DAS, Figure 2. We observed the root nodules at 570 DAS only in A. falcata saplings under full irradiance. In contrast, we did not detect root nodules in S. adstringens individuals in both irradiance regimes at 240, 360 and 570 DAS. 

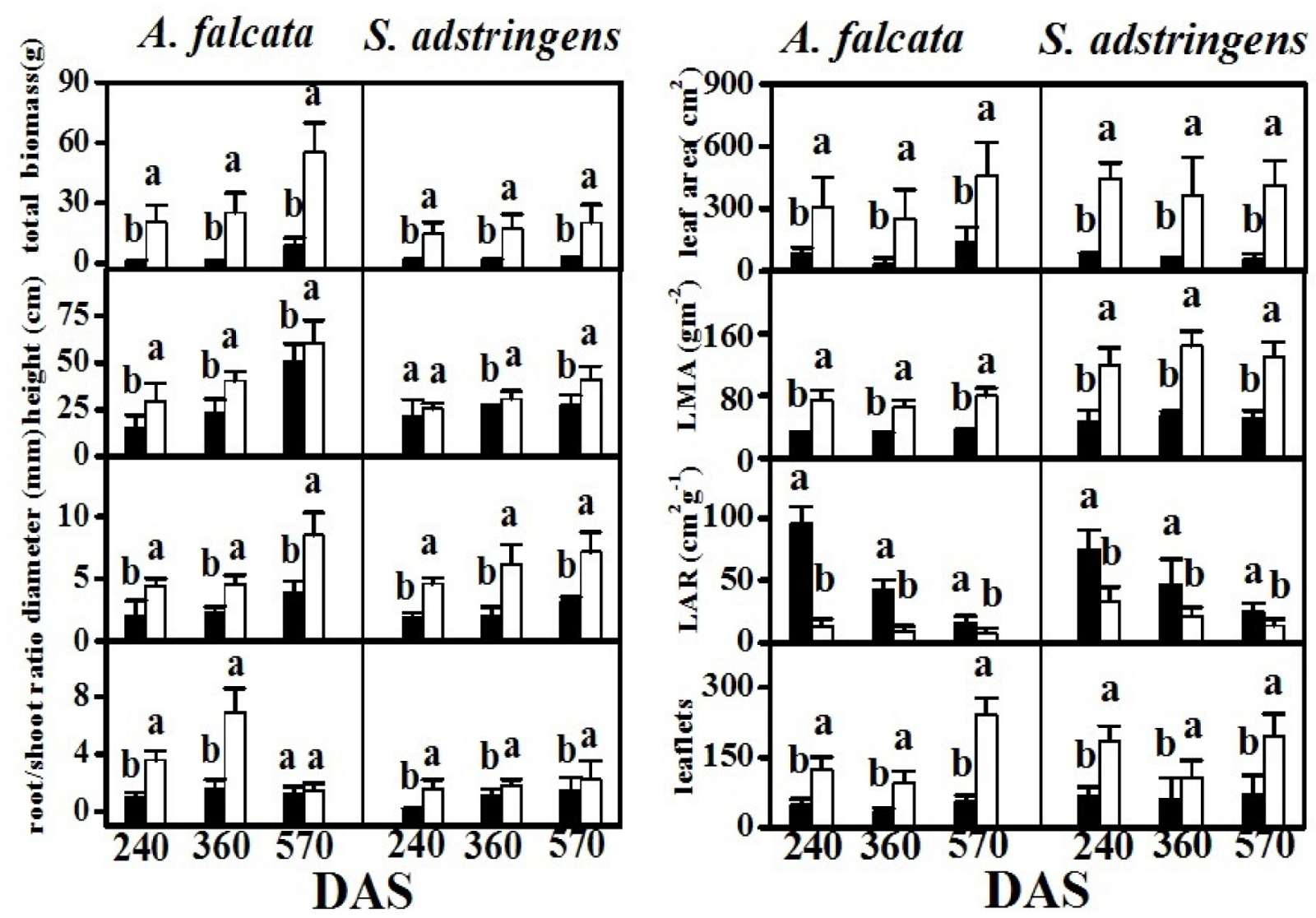

Figura 2. Mean (bars, $n=10$ individuals) and standard deviation (lines on bars) values obtained in $A$. falcata and S. adstringens grown under full solar irradiance in open (empty bars) and in the understory (solid bars) areas at 240, 360 and 570 days after sowing (DAS). Left side columns of panels: total biomass; height; stem diameter; and root/shoot biomass ratio. Right side columns of panels: total leaf area; leaf mass per area (LMA); leaf area ratio (LAR) and the number of leaflets. Same letters above the bars indicate that the mean values did not differ significantly $(p<0.05)$ at the same age (DAS) between irradiance regimes concerning each variable in the same species.

Figure 2. Média (barras, $n=10$ indivíduos) e desvio padrão (linhas acima das barras) obtidos em plantas de $A$. falcata e $S$. adstringens cultivadas sob irradiância solar plena em área aberta (barras vazias) e no sub-bosque (barras sólidas) aos 240, 360 e 570 dias após a semeadura (DAS). Painéis à esquerda: biomassa total, altura, diâmetro do caule, e relação da biomassa raiz/parte aérea. Painéis à direita: área foliar total, massa foliar por área (LMA), razão de área foliar (RAF) e número de folíolos. As mesmas letras acima das barras indicam que os valores médios não diferem significativamente $(p<0,05)$ na mesma idade (DAS) entre os regimes de irradiância na mesma variável para a mesma espécie.

Both species showed higher values of photosynthetic capacity on an area basis ( $\mathrm{A}_{\text {maxa' }}$ Figure 3 ) in sunny than in shade areas. In A. falcata and S. adstringens, the $A_{\operatorname{maxa}}$ was 52 and $54 \%$ higher in sunny versus shaded area, respectively (Table 1). In contrast, when the photosynthetic capacity was expressed on a mass basis $\left(\mathrm{A}_{\operatorname{maxm}}\right)$, an inverse tendency was detected with values of photosynthetic capacity higher in shaded versus sunny areas (Figure 3 and Table 1). In open areas, both A. falcata and $S$. adstringens presented values of $\mathrm{A}_{\text {maxa }} \mathrm{Lc}, \mathrm{R}_{\mathrm{d}^{\prime}}$ and LSP approximately 50, 35, 36 and 49\% higher than in the shade, respectively, Table 1 . The potential photosynthetic rate $\left(\mathrm{A}_{\mathrm{pot}}\right)$ was two times higher in sunny versus shaded area in both species (Figure 4 and Table 1 ). The $\varepsilon$ values increased by $165 \%$ in A. falcata; and by $126 \%$ in S. adstringens; under full solar irradiance, Table 1 . On the other hand, the apparent quantum yield values $(\alpha)$ were similar for both species irrespective the irradiance regime (Table 1). 


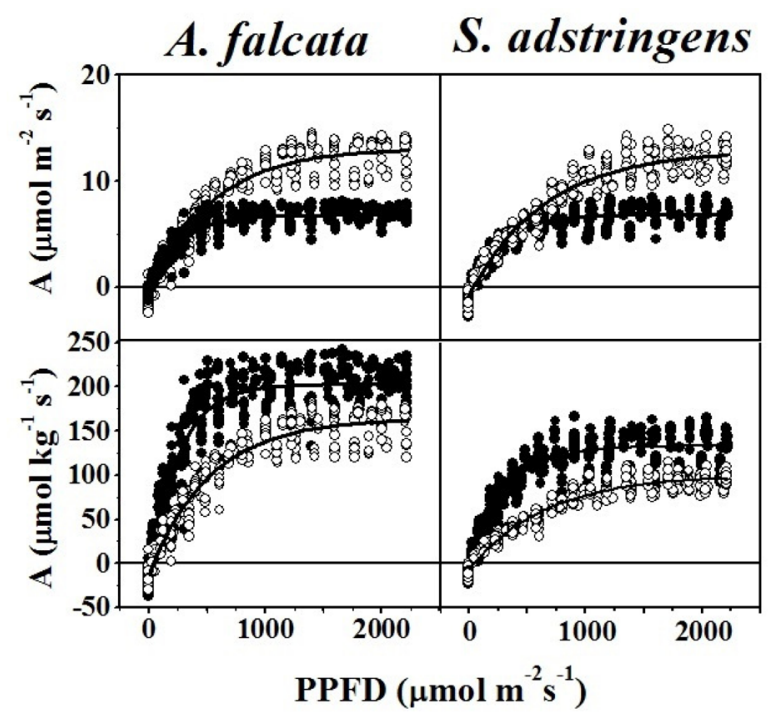

Figura 3. Net photosynthesis based on area $\left(A_{\text {maxa }}, \mu \mathrm{mol} \mathrm{m} \mathrm{m}^{-2} \mathrm{~s}^{-1}\right)$ and on mass $\left(A_{\operatorname{maxm}} \mu \mathrm{mol} \mathrm{kg}^{-1} \mathrm{~s}^{-1}\right)$ related to pho-

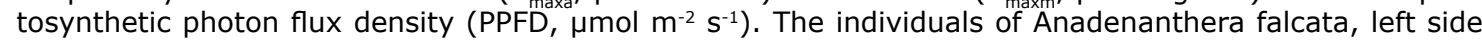
panels, and Stryphnodendron adstringens, right side panels, were maintained in an open area under full irradiance (empty symbols) and in shade in the understory (solid symbols). Each adjustment resulted from three hyperbolic curves obtained at 240, 360 and 570 days after sowing in each species expressed in area or mass basis under sunny and shaded regimes.

Figure 3. Fotossíntese líquida expressa em área $\left(A_{\text {maxa }} \mu \mathrm{mol} \mathrm{m} \mathrm{m}^{-2} \mathrm{~s}^{-1}\right)$ e em massa $\left(A_{\text {maxm }} \mu \mathrm{mol} \mathrm{kg}^{-1} \mathrm{~s}^{-1}\right)$ em função da densidade de fluxo de fótons fotossinteticamente ativos (PPFD, $\mu \mathrm{mol} \mathrm{m} \mathrm{m}^{-2} \mathrm{~s}^{-1}$ ). Os indivíduos de Anadenanthera falcata, painéis à esquerda, e Stryphnodendron adstringens, painéis à direita, foram mantidos em área aberta sob irradiância solar plena (símbolos abertos) e em um sub-bosque sob sombreamento (símbolos sólidos). Cada ajuste foi realizado com três curvas hiperbólicas obtidas aos 240, 360 e 570 dias após a semeadura expressa em área ou em massa em cada regime de irradiância em ambas espécies.

Tabela 1. Mean values \pm standard deviation $(n=3)$ of maximum photosynthesis expressed on area $\left(A_{\text {maxa }}\right)$ and mass $\left(A_{\operatorname{maxm}}\right)$ basis; light compensation point (LC); light saturation point (LSP); apparent quantum yield of net $\mathrm{CO}_{2}$ assimilation $(a)$, respiration in the dark $\left(\mathrm{R}_{\mathrm{d}}\right)$; maximum photosynthesis expressed on an area basis related to $\mathrm{CO}_{2}$ saturating concentration $\left(A_{\text {pot }}\right)$, and apparent carboxylation efficiency $(\varepsilon)$ in completely expanded leaflets of $A$. falcata and $S$. adstringens cultivated under full solar irradiance (Sun) and in the understory (Shade) at 240,360 and 570 days after sowing.

Table 1. Valores médios \pm desvio padrão $(n=3)$ da fotossíntese máxima expressa em área $\left(A_{\text {maxa }}\right)$ e em massa $\left(A_{\operatorname{maxm}}\right)$, ponto de compensação à luz (LC), ponto de saturação à luz (LSP), rendimento quântico aparente da assimilação líquida de $\mathrm{CO}_{2}(a)$, respiração no escuro $\left(R_{d}\right)$, fotossíntese máxima potencial expressa em área sob concentração de saturação de $\mathrm{CO}_{2}\left(\mathrm{~A}_{\mathrm{not}}\right)$, e eficiếncia aparente de carboxilação $(\varepsilon)$ em folíolos expandidos de $A$. falcata e de $S$. adstringens cultivados em área aberta sob irradiação solar total (Sun) e no sub-bosque (Shade) aos 240, 360 e 570 dias após a semeadura.

\begin{tabular}{|c|c|c|c|c|}
\hline \multirow{2}{*}{ Leaf physiological traits $(n=3)$} & \multicolumn{2}{|c|}{ A. falcata } & \multicolumn{2}{|c|}{ S. adstringens } \\
\hline & Sun & Shade & Sun & Shade \\
\hline$A_{\operatorname{maxa}}\left(\mu \mathrm{mol} \mathrm{CO}{ }_{2} \mathrm{~m}^{-2} \mathrm{~s}^{-1}\right)$ & $13.1 \pm 1.7$ & $6.8 \pm 0.3$ & $12.9 \pm 0.8$ & $6.9 \pm 0.4$ \\
\hline$A_{\operatorname{maxm}}^{\operatorname{maxa}}\left(\mu \mathrm{mol} \mathrm{CO} \mathrm{Cg}^{-1} \mathrm{~s}^{-1}\right)$ & $164.4 \pm 13.1$ & $203.2 \pm 62.2$ & $99.9 \pm 5.8$ & $133.1 \pm 10.7$ \\
\hline $\operatorname{Lc}\left(\mu \mathrm{mol}\right.$ photon $\left.\mathrm{m}^{-2} \mathrm{~s}^{-1}\right)$ & $38.2 \pm 7.6$ & $13.7 \pm 4.0$ & $40.5 \pm 13.9$ & $15.9 \pm 3.2$ \\
\hline LSP $\left(\mu \mathrm{mol}\right.$ photon $\left.\mathrm{m}^{-2} \mathrm{~s}^{-1}\right)$ & $1249 \pm 248$ & $619 \pm 78$ & $1574 \pm 72$ & $783 \pm 114$ \\
\hline$\alpha\left(\right.$ photon $\left.\mathrm{CO}_{2}^{-1}\right)$ & $0.024 \pm 0.01$ & $0.026 \pm 0.006$ & $0.021 \pm 0.01$ & $0.022 \pm 0.004$ \\
\hline $\mathrm{R}_{\mathrm{d}}\left(\mu \mathrm{mol} \mathrm{CO} \mathrm{CO}^{-2} \mathrm{~s}^{-1}\right)$ & $0.99 \pm 0.13$ & $0.36 \pm 0.13$ & $0.81 \pm 0.02$ & $0.34 \pm 0.07$ \\
\hline$A_{\text {pot }}\left(\mu \mathrm{mol} \mathrm{CO} \mathrm{CO}^{-2} \mathrm{~s}^{-1}\right)$ & $24.2 \pm 2.5$ & $12.8 \pm 1.1$ & $23.4 \pm 0.4$ & $11.1 \pm 1.0$ \\
\hline$\varepsilon\left(\mathrm{mol} \mathrm{m}^{-2} \mathrm{~s}^{-1}\right)$ & $0.077 \pm 0.02$ & $0.029 \pm 0.01$ & $0.086 \pm 0.07$ & $0.038 \pm 0.01$ \\
\hline
\end{tabular}

In short, we detected significant alterations in the carbon balance and biomass partitioning according to the available irradiance in both species. It happened during the first year of growth free of water shortage up to 570 DAS. In addition, S. adstringens could not survive in shade up 1140 DAS, despite all previous alterations in carbon gas exchange, biomass gain, and biomass partitioning.

\section{DISCUSSION}

Morphological and physiological adjustments in shaded areas of Cerrado vegetation such as the increase in leaf/area ratio, and the decreasing of LMA, $\mathrm{R}_{\mathrm{d}^{\prime}}$ and Lc could offset in part the reduction of net photosynthesis under low irradiance availability (HOFFMANN; FRANCO, 2003; RONQUIM 
et al.. 2009). Our results showed these adjustments in the first year of plant life cycle up to 570 DAS in individuals free of water shortage. Such morphological and physiological alterations were able to maintain $100 \%$ survivorship in A. falcata but not in S. adstringens. Indeed, the seedlings of Cerrado tree species such as Kilmeyera coriacea, Zeyheria montana (HOFFMANN, 2000) and Bowdichia virgilioides (KANEGAE et al., 2000) experienced high mortality in shaded areas in Cerrado vegetation. Nevertheless, these seedlings underwent unpredictable dry spells occurring in the wet season during early growth under natural conditions.

In this study, we maintained the soil near field capacity and the seedlings grew free from root competition from other species up to 570 DAS. Therefore, low irradiance rather than drought resulted in the mortality in shade of S. adstringens (24\%) up to 570 DAS. Additionally, all S. adstringens individuals transplanted to the shade under natural conditions died before the onset of the dry season at 1140 DAS. Therefore, in the understory of Cerradão physiognomy, the attenuation of the excessive temperature by canopy cover and the suppression of competition with grasses probably do not provide advantages to carbon balance in studied species, chiefly to $S$. adstringens after 1140 DAS.

After the first harvest at 240 DAS, the biomass allocation to leaves declined, resulting in lower LAR in both species irrespective of the irradiance condition. Indeed, the root biomass allocation indicated by root/shoot ratio was greater in sunny versus shaded area, except for A. falcata at 570 DAS. In general, our results showed biomass allocation favoring roots in both species irrespective of the irradiance regime. These results are consistent with other works on young woody species of Cerrado vegetation in which biomass allocation privileged roots (FRANCO, 2002; HOFFMANN; FRANCO, 2003; RONQUIM et al. 2009). The coarse roots of woody Cerrado species are suitable for storing carbohydrates and nutrients; they also facilitate vegetative propagation (IMATOMI et al. 2014) and greater rooting depth, which permits access to water during dry periods (RAWITSCHER et al., 1943; RIZZINI; HERINGER, 1962). Therefore, the shaded environment predominantly limits the underground accumulation of biomass, resulting in low values of root/shoot ratio. Indeed, the low root biomass presented by $S$. adstringens, mainly at 570 DAS, is a competitive disadvantage in the understory compared with $A$. falcata. On the other hand, the nodulation under full irradiance at 570 DAS in A. falcata indicates sufficient production of carbohydrates to sustain the symbiotic activity as a strategy for enhancing nitrogen acquisition. In effect, plants of Anadenanthera peregrina var. falcata with 10-months-old infected with rizhobia grew better than non-inoculated and showed higher nitrogen concentration in xylopodium and shoots (GROSS et al. 2002). Besides, one-year-old Adenanthera falcata grown in greenhouse showed significant growth and development improvements in the shoot or root when inoculated with rhizobia and spores of mycorrhizal fungi from adult cerrado individuals (ALMEIDA; RAYMUNDO-JUNIOR, 2006). The high mycotrophism of A. falcata (CARNEIRO et al. 1996) could facilitate its establishment, growth, and survival on low-fertility cerrado soils, especially in open areas where the carbon balance is more favorable to establish symbioses with bacteria and fungi.

The decreasing of more than $50 \%$ of $A_{\text {maxa }}$ with a reduction of leaf area in the shade surely resulted in the short net assimilation of carbon per plant in both species. Irradiance values less than 600 $\mu \mathrm{mol} \mathrm{m} \mathrm{m}^{-2} \mathrm{~s}^{-1}$ sharply restrict $\mathrm{CO}_{2}$ assimilation in adult Cerrado plants (PRADO; MORAES, 1997). Definitely, plants of $S$. adstringens demanded PPFD higher than $600 \mu \mathrm{mol} \mathrm{m}^{-2} \mathrm{~s}^{-1}$ for photosynthesis saturation (LEMOS-FILHO et al. 2004). Kanegae et al. (2000) estimated $A_{\max }$ values varying between $40-70 \%$ in Bowdichia virgilioides seedlings in the understory of woody Cerradão compared with Campo sujo, a more open Cerrado physiognomy. According to Ronquim et al. (2009), the decrease in $\mathrm{A}_{\max }$ in seedlings of Copaifera langsdorffii occurred in the shade mainly in a dry season when the precarious leaf water status and photo-inhibition limited net photosynthesis to half of that measured in the wet season. In fact, the potential photochemical efficiency (Fv/Fm) declined in the shade evidencing photo-inhibition in photosystem II in seedlings of $C$. langsdorffi in the dry season (RONQUIM et al. 2009). On the other hand, our results showed that the impact of low irradiance availability is significantly detrimental to carbon balance even in plants free of water stress. Therefore, a combination between drought and low irradiance regime could be sufficient to define the establishment of many woody species of Cerrado vegetation. This stressful combination takes place in understory of the densest woody physiognomy, the Cerradão, where the competition for water and light is more severe. 
One of the best ways to decrease the negative component of carbon balance in the shade is the reduction of $R_{d^{\prime}}$ which could result in an increase in carbon use efficiency $\left(A_{\text {maxa }} / R_{d}\right)$. The ratio $A_{\text {maxa }} / R_{d}$ was half in shade in our work, when $R_{d}$ values were 63 and $58 \%$ about the sunny area in A. falcata and S. adstringens, respectively (Table 1). On the other hand, the reduction in Rd was not sufficient to counteract the negative impact on carbon balance under lesser irradiance availability and, consequently, we found a significant reduction of biomass accumulation in understory in both species. Alternatively, the apparent quantum yield $(\alpha)$ did not differ between irradiance regimes. Indeed, there was no patent difference in the initial slope between sunny and shaded leaves in both species, Figure 4. Therefore, the light compensation point (Lc) is low in the shaded leaves not because they use irradiance more efficiently but rather because their respiration is less intense in the dark (WALKER, 1992). The lower $\varepsilon$ values found for both species in the shade probably reflect the low Rubisco concentration in chloroplasts. Low values of $\varepsilon$ and $A_{\max }\left(A_{\operatorname{maxa}}\right.$ and $\left.A_{\text {pot }}\right)$ in the shade are robustly linked to the limitations of enzymatic processes in matrix rather than in the energy transfer processes in the thylakoids of chloroplasts (WALKER, 1992). Indeed, the values of $\varepsilon$ were twice as high in open versus shaded area in S. adstringens and A. falcata.

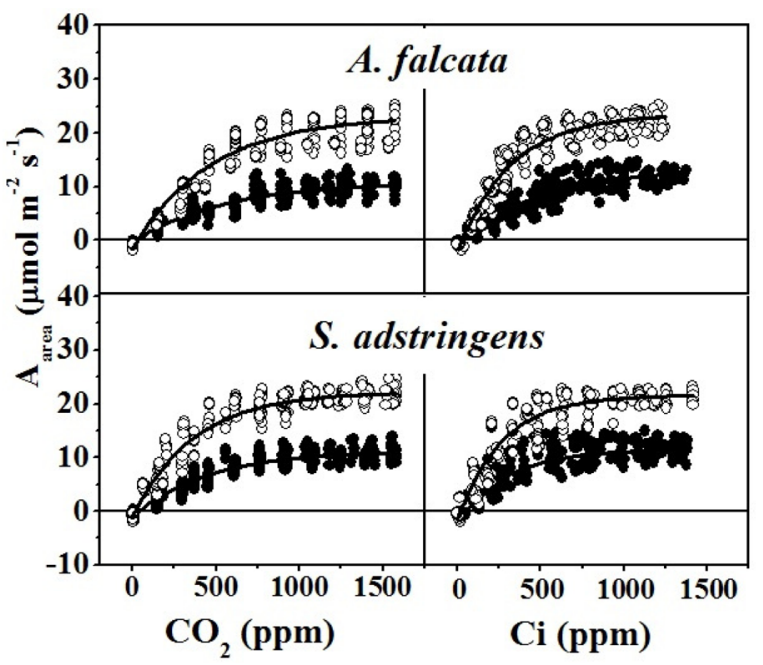

Figura 4. Net photosynthesis on area basis $\left(\mathrm{A}_{\text {area }}\right)$ related to atmospheric $\left(\mathrm{CO}_{2}\right.$, left side panels $)$ and sub-stomatal ( $\mathrm{Ci}$, right side panels) $\mathrm{CO}_{2}$ concentrations. The individuals of Anadenanthera falcata, upper panels, and Stryphnodendron adstringens, lower panels, were maintained in an open area under full irradiance (empty symbols) or in shade (solid symbols). Each adjustment resulted from three hyperbolic curves obtained at 240, 360 and 570 days after sowing in each species in sunny and shaded areas.

Figure 4. Fotossíntese líquida expressa em área $\left(A_{\text {rea }}\right)$ em função da concentração atmosférica $\left(\mathrm{CO}_{2}\right.$, painéis à esquerda) e sub-estomática ( $\mathrm{Ci}$, painéis à direita) de $\mathrm{CO}_{2}$. Os indivíduos de Anadenanthera falcata, painéis acima, e de Stryphnodendron adstringens, painéis abaixo, foram mantidos em uma área aberta sob irradiância total (símbolos vazios) e sob sombreamento em um sub-bosque (símbolos sólidos). Cada ajuste foi realizado com três curvas hiperbólicas obtidas aos 240, 360 e 570 dias após a semeadura em cada regime de irradiância em ambas espécies.

The studied species showed important changes at several levels of plant organization according to the irradiance regime. These alterations occurred from the molecular level, as indicated by adjustments in $\varepsilon$, to the whole individual, as highlighted by the differences in total biomass accumulation and biomass partitioning between irradiance treatments. Therefore, in addition to the leaf morphological qualifications at the tissue levels (leaf area and LMA); the physiological traits directly related to mitochondria $\left(\mathrm{R}_{\mathrm{d}}\right)$ and to chloroplasts $\left(\mathrm{A}_{\max ^{\prime}} \mathrm{Lc}\right.$, LSP, and e) were modified in both species. Through those modifications, from molecular to the whole plant, both species could make a better use of irradiance in $\mathrm{CO}_{2}$ assimilation and an improved use of the $\mathrm{CO}_{2}$ already assimilated.

Both species performed better in sunny than in shaded areas. Alternatively, A. falcata presented $100 \%$ survival while all individuals of $S$. adstringens died in the shade. It indicates a better capacity of $A$. falcata to adjust its morphological and physiological qualities resulting in adequate adaptation to the understory. Also, A. falcata accumulated twice-total biomass than S. adstringes at 570 DAS in sunny area. Eight months after planting in an open area, 95\% of A. falcata seedlings survived and their growth was vigorous under field conditions (DURIGAN, 1990). This behavior of $A$. falcata explains in part why this species is widespread and sometimes dominant in some Cerrado 
physiognomies. The growth performance of $A$. falcata saplings indicates their great potential in the re-vegetation of degraded areas of Cerrado, including in the shaded areas. S. adstringens would be able to exploit more opened Cerrado areas such as sensu stricto and Campo sujo physiognomies, and at the boundary line areas with Cerradão or even deforested areas where Cerrado vegetation has been significantly consumed by fire. This success in open areas could be boosted by the reduced preference of $S$. adstringens for different types of cerrado soils (SILVA-JUNIOR; SARMENTO, 2009). On the other hand, there are limits regarding the growth and propagation of $S$. adstringens because of bark extraction, which causes the premature death of trees; the high incidence of insect attacks or immature abortion of seeds, and the harvesting by the charcoal industry (CORRÊA et al, 2012).

On one hand, our study demonstrated how and how much the studied species could overcome the constraints imposed by irradiance attenuation in Cerradão growing free of water stress. On the other hand, we could show the advantages of the open area for growth, development and photosynthetic performance in the early stages of the life cycle of A. falcata and S. adstringens under full solar irradiation and free of water shortage.

\section{CONCLUSIONS}

The natural irradiance availability independently affected several levels of plant organization in both species, determining the pattern of development and the survival from early growth. The studied species showed a more favorable carbon balance and growth performance in sunny than in shaded areas when growing free of water shortage. The irradiance availability per se is one of the most significant environmental conditions for tree growth, development and establishment in Cerrado physiognomies.

\section{ACKNOWLEDGMENTS}

We thank the scholarships granted in Brazil by the Foundation for Research of São Paulo State, Brazil (FAPESP) and by the National Research Council (CNPq, Brazil) to the first and second authors, respectively.

\section{REFERENCES}

ALMEIDA. A. F; RAYMUNDO-JUNIOR, O. Crescimento de mudas de Anadenathera falcata em casa de vegetação inoculadas com rizóbio e micorrizas. Holos Environment, Rio Claro, v. 6, n. 1, p. 22-30, 2006.

CAEMMERER, S. Biochemical models of leaf photosynthesis: Techniques in Plant Science. Collingwood: CSIRO Publishing, 2000. 165 p.

CARNEIRO, M. A. C.; SIQUEIRA, J. O.; MOREIRA, F. M. S.; CARVALHO, D.; BOTELHO, A. S.; JUNIOR, O. J. S. Fungo micorrízico e superfosfato no crescimento de espécies arbóreas tropicais. Scientia Forestalis, Piracicaba, n. 50, p. 21-36, 1996.

CORNELISSEN J. H. C.; LAVOREL, S.; GARNIER, E.; DÍAZ, S.; BUCHMANN, N.; GURVICH, D. E.; REICH, P. B.; TER STEEGE, H.; MORGAN, H. D.; VAN DER HEIJDEN M. G. A.; PAUSAS, J. G.; POORTER, H. A handbook of protocols for standardised and easy measurement of plant functional traits worldwide. Australian Journal of Botany, Queensland, v. 51, n. 4, p. 335-380, 2003.

CORRÊA, V. S.; CERDEIRA, A. L; FACHIN, A. L.; BERTONI, B. W.; PEREIRA, P. S.; FRANÇA, S. C.; MOMM, H. G.; MORAES, R. M.; PEREIRA, A. M. S. Geografical variation and quality assessment of Stryphnodendron adstringens (Mart.) Coville within Brazil. Genetic Resources and Crop Evolution, v. 59, n. 7, p. 1349-1356, 2012.

DURIGAN, G. Taxa de sobrevivência e crescimento inicial das espécies em plantio de recomposição da mata ciliar. Acta Botânica Brasílica, São Paulo, v. 4, n. 2, supl. 1, p. 35-40, 1990. 
DURIGAN, G.; SIQUEIRA, M. F.; FRANCO, G. A. D. C.; BRIDGEWATER, S.; RATTER, J. A. The vegetation of priority areas for Cerrado conservation in São Paulo state, Brazil. Edinburgh Journal of Botany, v. 60, n. 2, p. 217-241, 2003.

EITEN, G. The Cerrado Vegetation of Brazil. Botanical Review, Lancaster, v. 38, n. 2, p. 201-341, 1972.

FRANCO, A. C. Biodiversidade de forma e função: implicações ecofisiológicas das estratégias de utilização de água e luz em plantas lenhosas de Cerrado. In: SCARIOT, A.; SOUSA-SILVA, J.C.; FELFILI, J.M. (Orgs). Cerrado: ecologia, biodiversidade e conservação. Ministério do Meio Ambiente, Brasília, p. 179-196, 2005.

FRANCO, A. C. Ecophysiology of woody plants. In: OLIVEIRA, O.S.; MARQUIS, R.J. (eds). The Cerrados of Brazil. New York: Columbia University Press, 2002. p. 178-197.

GROSS, E.; CORDEIRO, L.; CAETANO, F.H. Nodule ultrastructure and initial growth of Anadenanthera peregrina (L.) Speg, var. falcata (Benth.) Altschul plants infected with Rizhobia. Annals of Botany, Oxford, v. 90, n. 2, p. 175-183, 2002.

HARIDASAN, M. Nutritional adaptation of native plants of the cerrado biome in acid soils. Brazilian Journal of Plant Physiology, Campos dos Goytacazes, v. 20, n. 3, p. 183-195, 2008.

HOFFMANN, W. A. Post-establishment seedlings success in the Brazilian Cerrado: a comparison of savanna and forest species. Biotropica, v. 32, n. 1, p. 62-69, 2000.

HOFFMANN, W. A.; FRANCO, A. C. Comparative growth analysis of tropical forest and savanna woody plants using phylogenetically independent contrasts. Journal of Ecology, v. 91, n. 3, p. 475-484, 2003.

IMATOMI, M.; SOUZA, J. P.; GUALTIERI, S. C. J.; FERREIRA, A. G. The role of root buds in the regeneration of Casearia sylvestris Swartz (Salicaceae) in the cerrado, São Carlos, São Paulo state, Brazil. Hoehnea, São Paulo, v. 41, n. 3, p. 345-352, 2014.

KANEGAE, M. F; BRAZ, V. S.; FRANCO, A. C. Efeitos da disponibilidade sazonal de água e luz na sobrevivência de Bowdichia virgilioides em duas fitofisionomias típicas dos Cerrados do Brasil Central. Revista Brasileira de Botânica, v. 23, n. 4, p. 459-468, 2000.

LEMOS-FILHO, J. P.; GOULART, M. F.; LOVATO, M. B. Chlorophyll fluorescence parameters in populations of two legume trees: Stryphnodendron adstringens (Mart.) Coville (Mimosoideae) and Cassia ferruginea (Schrad.) Schrad. ex DC. (Caesalpinoideae). Revista Brasileira de Botânica, São Paulo, v. 27, n.3, p. 527-532, 2004.

MONTEIRO, J. A. F; PRADO, C. H. B. A. Apparent carboxylation efficiency and relative stomatal and mesophyll limitations of photosynthesis in an evergreen Cerrado species during water stress. Photosynthetica, v.44, n. 1, p. 39-45, 2006

OLIVEIRA-FILHO, A.T.; SHEPHERD, G.J.; MARTINS, F.R.; STUBBLEBINE W.H. Environmental factors affecting physiognomic and floristic variation in area of Cerrado of central Brazil. Journal of tropical Ecology, Cambridge, v. 5, n. 4, p. 413-431, 1989.

OLIVEIRA-FILHO A. T.; RATTER, J. A. Vegetation physiognomies and woody flora of the Cerrado Biome. In: OLIVEIRA, P.S.; MARQUIS, R.J. (eds). The Cerrados of Brazil. New York: Columbia University Press, 2002. p. $91-120$.

PRADO, C. H. B. A.; MORAES, J. A. P. V. Photosynthetic capacity and specific leaf mass in twenty woody species of Cerrado vegetation under field conditions. Photosynthetica, v. 33, n. 1, p. 103-112, 1997. 
Ronquim et al. - Irradiance availability and growth of leguminous tree of cerrado

PRADO, C. H. B. A.; RONQUIM, C. C.; PERON, M. C. C. Balanço de carbono em duas espécies lenhosas de Cerrado cultivadas sob irradiação solar plena e sombreadas. In: SCARIOT, A.; SOUSA-SILVA, J.C.; FELFILI, J.M. (Orgs). Cerrado: ecologia, biodiversidade e conservação. Brasília: Ministério do Meio Ambiente, 2005. p.197-215.

PRADO, C. H. B. A.; WENHUI, Z.; ROJAS, M. H. C.; SOUZA, G. M. Seasonal leaf gas exchange and water potential in a woody cerrado species community. Brazilian Journal Plant Physiology, Campos dos Goytacazes, v. 16, n. 1, 7-16, 2004.

RAWITSCHER, F.; FERRI, M. G.; RACHID, M. Profundidade dos solos e vegetação em campos cerrados do Brasil Meridional. Anais da Academia Brasileira de Ciências, Rio de Janeiro, v. 15, n. 4, p. 267-294, 1943.

RIZZINI, C. T.; HERINGER, E.P. Studies on the underground organs of trees and shrubs from some southern Brazilian savannas. Anais da Academia Brasileira de Ciências, Rio de Janeiro, v. 34, n. 2, p. 235-247, 1962.

RONQUIM, C. C.; PRADO, C. H. B. A.; SOUZA, J. P. Estabelecimento e crescimento de plantas jovens de Vochysiatucanorum Mart. (Vochysiaceae) em área aberta e sombreada sob dossel florestal. Scientia Forestalis, Piracicaba, v.41, n. 97, p. 121-130, 2013.

RONQUIM, C.C.; PRADO, C.H.B.A.; SOUZA, J.P. Growth, photosynthesis and leaf water potential in young plants of Copaiferalangsdorffii Defs. (Caesalpiniaceae) under contrasting irradiances. Brazilian Journal of Plant Physiology, Campos dos Goytacazes, v. 21, n. 3, p. 197-208, 2009

RONQUIM, C. C.; PRADO, C. H. B. A.; DE PAULA, N. F. Growth and photosynthetic capacity in two woody species of cerrado vegetation under different radiation availability. Brazilian Archives of Biology and Technology, Curitiba, v. 46, n. 2, p. 243-252, 2003.

SILVA-JUNIOR, M. C.; SARMENTO, T. S. Comunidades lenhosas no cerrado sentido estrito em duas posições topográficas na estação ecológica do Jardim Botânico de Brasília, DF, Brasil. Rodriguesia, Rio de Janeiro, v. 60, n. 2, p. 277-294, 2009.

SOUZA, J. P.; PRADO, C. H. B. A.; ALBINO, A. L. S.; DAMASCOS, M. A.; SOUZA, G. M. Network analysis of tree crows distinguishes functional groups of Cerrado species. Plant Ecology, Amsterdam, v. 212, n. 1, p. 1119, 2011.

WALKER, D. Tansley review n ${ }^{0}$ 36. Excited leaves. New Phytologist, Oxford, v. 121, n. 3, p. 325-345. 1992

Recebido em 20/10/2016

Aceito em 22/09/2017 